\title{
Identification of Musculoskeletal Disorder Complaint, Dermatitis Incident and Respiratory Disorder in Smoked Fish Worker
}

\author{
Yuliani Setyaningsih*, Ida Wahyuni, Ekawati \\ Occupational Safety and Health Department, Public Health Faculty, Diponegoro University, \\ Semarang
}

\begin{abstract}
Smoked fish is one of the most popular side dishes. Workers in the smoked fish industry do their work with sitting postures in a stool. This posture causes many complaints of musculoskeletal in workers. They are always in contact with water that causing itching and redness. The fogging process of the fish makes the work area full of smoke, so workers complain the shortness of breath. Besides, the work area was always flooded and dirty. The purpose of this study was to describe the hygiene sanitation condition, musculoskeletal complaints, the incidence of dermatitis and respiratory disorder. This research was a quantitative research with cross sectional approach. The study was conducted at a smoked fish center in Bonang, Demak, Central Java. Research subjects as many as 80 people were taken randomly. Data were collected using a questionnaire and analyzed descriptively. The results showed the majority of workers were female by $72.5 \%$, the majority of workers aged $\geq 35$ years by $66,3 \%$ and the majority of workers had a working period of $<5$ years of $52.5 \%$. Health complaints experienced were $87 \%$ MSDs complaints, dermatitis $40 \%$ and respiratory complaints $76 \%$.
\end{abstract}

Keywords. smoked fish worker, musculoskeletal disorder, dermatitis incident, respiratory disorder

\section{Introduction}

The smoked fish center is one of the informal sector industries that is developing rapidly and supporting the economy of the fishing community, however this sector has a high health risk because workers do not pay attention to the rules and safety of work [1]. The process of fumigating fish in Indonesia was initially carried out traditionally using simple equipment and less attention to sanitary and hygienic aspects so that it could have an impact on health and the environment. The short chimney has an impact on air pollution and affect health. The pollution from solid and liquid waste discharges also results in air pollution due to the onset of foul odors. Poor installation of drains and unergonomic work postures cause

* Corresponding author: joeliani kesja undip@yahoo.com 
many health problems for workers [2]. The risk that was often experienced by smoked fish workers was muscoloskeletal disorders (MSDs). Musculoskeletal disorders were muscueloskelatal system disorders due to unnatural work posture performance. Such as work positions that cause musculoskeletal complaints and fatigue on workers. WHO and ILO estimate that fatigue causes death, there were 2 million workers die due to work related accident caused of fatigue [3].

Smoked fish production sites have poor sanitary hygiene. Use of dirty water during the production process caused irritants and symptoms of dermatitis in workers. Occupational contact dermatitis was $90 \%$ of all cases related to cutaneous disorders. And $80 \%$ of them were irritant contact dermatitis and the rest were allergic contact dermatitis [4].

The production of smoked fish processes and also preserves fish by putting fish in a furnace that produces a lot of smoke. Health risks that can be experienced by workers include coughing and shortness of breath. High levels of $\mathrm{CO}$ in the respiratory air caused shortness of breath and also be a trigger for fatigue. Smoke can produce compounds that were not safe for health. Some carcinogenic compounds such as benzo (a) pyrene were present in smoke products. Smoked fish process was a house-scale industrial process that can cause air pollution due to smoke generated. Smoke from that process consists of $\mathrm{CO}$, formaldehyde, ketones, PAHs, esters, phenols, and dust particles [2]. Persistent exposure to the worker for years caused a decrease of worker's lung function and caused damage to organs in the respiratory tract. Secret deposits and damage to respiratory tract organs cause the flow of oxygen entering the body to decrease. This is what can cause shortness of breath [5].

The fish smoke center in Bonang, Demak district is one of the fish processing pilot projects. The preliminary survey stated that $20 \%$ of workers complained of neck, back and leg pain after work, $10 \%$ of them complained of itching at hand. $15 \%$ of workers also complained of shortness of breath during work. Therefore researchers intend to conduct studies to identify health complaints due to smoked fish making.

\section{Methods}

This research was a quantitative study with a cross sectional design. The study was conducted at smoked fish center in the Bonang area, Demak Central Java. Research subjects as many as 80 people were selected by random sampling technique. Data were collected using a questionnaire, scales and microtoise. The variables studied included were the characteristics of respondents (sex, age, work period, BMI), musculoskeletal and dermatitis complaints and respiratory disorder. Data were analyzed descriptively with frequency distribution and presented in the form of diagrams and graphs.

\section{Result and Discussion}

Smoked fish center has special production sites. However, there were still a few things that need attention. Among the floors where the production was dirty and muddy due to poor drainage system. Lack of ventilation can be seen from the dense smoke around the production site. Although most of fish processors already used chimneys, smoke from the process of smoking with coconut shell fuel accumulated in the room, and also produced smoke that looks black that make poignant in the eyes and caused shortness of breath on workers. There was no adequate hand washing area and was not equipped with soap. In addition, the work station was also not ergonomic, workers feel tired and complain of frequent aches and stiff muscles. Workplaces that have poor sanitation will affect worker's 
health. The hot workplace climate and lack of ventilation will cause a lack of oxygen in the work environment, complaints of respiratory problems, fatigue and complaints of musculoskeletal in workers [6, 7].

The smoked fish center has a bad work station, for 8 hours the worker sits in unergonomic seats and didn't use personal protective equipment such as masks, protective goggles, aprons and booth shoes.

Table 1. Characteristics of Smoked Fish Workers

\begin{tabular}{ccc}
\hline Variables & f & $\mathbf{( \% )}$ \\
\hline Gender & & \\
Female & 58 & 72.5 \\
Male & 22 & 27.5 \\
Age & & \\
$\geq 35$ years & 53 & 66.33 \\
$<35$ years & 27 & 33.67 \\
Working & & \\
$\quad$ Period & 42 & 52.5 \\
$\geq 5$ years & 38 & 47.5 \\
$<$ 5 years & & \\
Nutrition & & \\
Status $(I M T)$ & 12 & 15.0 \\
Normal & 68 & 85.0 \\
$\quad$ Fat & & \\
\hline
\end{tabular}

Table 1 showed that most respondents were female $(72.5 \%)$ and aged over 35 years $(66.3 \%)$. After the age of 40 years a person will experience a decrease in physical strength and function of the body's capacity, in addition to the capacity of the lung function also decreases when a person on 50 years or older [8].

The more age and poor environmental conditions, the greater the possibility of lung function decline. Increased age results in a decrease in the maximum amount of oxygen that can be delivered from the lungs to the muscles or VO2max, which is caused by a decrease in maximum heart rate and maximum reserve volume. The need of energy continues to increase until finally decreasing after the age of 40 years decreasing energy requirements due to decreased physical strength [9].

Most respondents have a work period of less than 5 years $(52.5 \%)$. Although the work period is still short, working monotonously every day and breathing in fumes during the production process can cause fatigue and musculoskeletal complaints. There was a normal BMI of $15 \%$ and $85 \%$ over weight. Women workers who have normal nutritional status will have good work capacity and endurance. While female workers who have poor and excess nutritional status will lead to poor work performance and fatigue [10]. 
Table 2. Complaint of Musculoskeletal, Dermatitis Incident and Respiratory Disorder on Smoked Fish Workers

\begin{tabular}{lcc}
\hline \multicolumn{1}{c}{ Variables } & f & $(\mathbf{\%})$ \\
\hline $\begin{array}{l}\text { Musculoskeletal } \\
\text { Complaint }\end{array}$ & & \\
Yes & 70 & 87.5 \\
No & 10 & 12.5 \\
& & \\
Dermatitis Incident & & \\
Yes & 32 & 40.0 \\
No & 48 & 60.0 \\
Respiratory & & \\
Disorder & & \\
Yes & 60 & 75.0 \\
No & 20 & 25.0 \\
& & \\
\hline
\end{tabular}

Table 2 shows that more than $87 \%$ of respondents had musculoskeletal complaints. Complaints that are often experienced are stiff neck $85 \%$, back pain $90 \%$, foot tingling $95 \%$, aches in the shoulders and hands $75 \%$.

The process of producing smoked fish uses many repetitive activities with a standing position continuously and movements to reach, take, and bend. Work activities like this will certainly cause injury to the muscles, joints, ligaments and tentons. Such disorders were usually referred to as complaints of MSDs or complaints in the musculoskeletal system which is a condition with discomfort or even arising pain [11].

Studies related to MSDs complaints were mostly carried out in various companies and industries. As a study conducted by Ekawati, et al (2014) on stone-breaking workers in Leyangan Village, Semarang, it was found that as many as $40 \%$ of respondents felt complaints of MSDs in some parts of the body with a high level of risk. Most lower back pain was felt by $76.7 \%$ respondents of the total 30 respondents [12].

Table 2 shows that $40 \%$ of respondents experienced dermatitis complaints. Dirty work stations play a role in the occurrence of dermatitis. According to Lestari (2007: 58), workers who work longer hours of exposure and contact with irritants can cause damage to the outer skin cells. The longer exposure will further damage the skin cells to the inside and facilitate the occurrence of dermatitis. Short work periods can have the potential to cause health effects. This is influenced by other factors such as how long a person is exposed per day and contact with irritants. Short work periods can also have the potential to have an impact on health. This is because there are other factors such as how long a person is exposed per day and contact with irritants, so even though it has not been long to work to peel cassava may have experienced skin disorders before [13].

As many as $76 \%$ of respondents experienced respiratory disorders (shortness of breath and dry throat). Exposure to smoke that has been inhaled by workers for years caused a decrease in lung function in workers. This resulted the damage of the organs in the respiratory tract. Secretions that accumulate and damage the respiratory tract organs caused decreasing the flow of oxygen entering the body. Research conducted by Dewi Sinta Nirmala states that as many as 13 people or 52 percent of respondents have a risk of decreased lung function with the condition of the respondents working every day $>8$ hours a day in a fish fumigation place. ${ }^{5}$ Meanwhile, according to research conducted by Pranowowati (2007), the existing smoke contains chemicals that have the potential to cause a decrease in lung function in the form of particulates and gas components. Disorders experienced by smokers: 33 people experiencing cough, 28 people have cough with 
phlegm, 35 people experience shortness of breath and 30 people experience chest pain [14].

\section{Conclusion}

The results showed the majority of workers were female by $72.5 \%$, the majority of workers aged $\geq 35$ years by $66,3 \%$ and the majority of workers had a working period of $<5$ years of $52.5 \%$. Health complaints experienced were MSDs complaints $87 \%$, dermatitis $40 \%$ and respiratory complaints $76 \%$.

\section{Acknowledgement}

We would like to express our appreciation to all respondents who participated in this study.

\section{References}

1. R Parayogi, Y Setyaningsih, Suroto, Analysis of the Effect of Carbonmonoxide exposure and characteristics of workers on work-related fatigue in workers of fish smoking center. Int Journ of Ed and Soc Science Research Vol 2 no 05 ; (2019)

2. Soimah H, Purnaweni H, B Yulianto. Pengelolaan Lingkungan di Sentra Pengasapan Ikan Desa Wonosari Kecamatan Bonang Kabupaten Demak. In: Prosiding Seminar Nasional Pengelolaan Sumberdaya Alam dan Lingkungan. eprints.undip.ac.id/40731/1/088; 2013

3. Muizzudin A, Hubungan kelelahan dengan produktivitas karyawan, UNNES J Public Health : 2(4) 1-8; (2013)

4. Sasseville, Denis, Occupational contact dermatitis: Allergy, Ashtma and Clinical Immunology, vol 4, no 2 (summer), pp 59-63; (2008)

5. Nirmala D, CI Prasati. Konsentrasi PM2,5 dan Analisis Karakteristik Pekerja Terhadap Keluhan Kesehatan Pekerja Pengasapan Ikan Di Kelurahan Tambak Wedi Surabaya. J Pengolah dan Bioteknol Has Perikan;3(4); (2014)

6. Y Dharmawan, Y Setyaningsih, A Prasetyaningrum. Work environment and musculoskeletal complaints of grinding workers of brass crafts, Journal of Physics: Conference Series 1217 (1), 012160)

7. Y Setyaningsih, AH Husodo, I Astuti. Work Environment Factors and Their Influence on Urinary Chromium Levels in Informal Electroplating Workers; E3S Web of Conferences 31, 06007 )

8. I Wahyuni, Y Setyaningsih, Ekawati; Analysis of Work Capacity and Chromium Exposure on Lung Function Capacity in Metal Coating Worker; E3S Web of Conferences 125, 17001)

9. Dyer C. The interaction of ageing and lung disease. Chronic Respiratory Disease. 2012

10. RP Karmila, Y Setyaningsih, Nurjazuli; The Influence of Total Suspended Particulate (TSP), Carboksihemoglobin and Individual Characteristics of Vital Capacity of Lung Fish Craffickers in Fishing Center. Int J of Health, Education \& Social (IJHES) 3 (1), 36-47, (2020)

11. Tarwaka. Ergonomi Industri, Dasar-dasar Pengetahuan Ergonomi dan Aplikasi di Tempat Kerja. 2nd ed. Surakarta: Harapan Press; (2015) 
12. W. Thoyib Rivai, -. Ekawati, and S. Jayanti, "Hubungan Tingkat Risiko Ergonomi Dan Masa Kerja Dengan Keluhan Muskuloskeletal Pada Pekerja Pemecah Batu," Jurnal Kesehatan Masyarakat (e-Journal), vol. 2, no. 3, pp. 227-231, Sep. (2014). [Online])

13. Lestari, Fatma. Faktor-faktor yang Berhubungan dengan Dermatitis Kontak pada Pekerja di PT. Inti Pantja Press Industri. Makara Kesehatan,2 (2): 61-68); (2007)

14. Pranowowati, Puji; Induksi Partikel Terhirup Dalam Asap Terhadap Kapasitas Fungsi Paru Pada Pengrajin Pengasapan Ikan di Kelurahan Bandarharjo Kecamatan Semarang Utara Kota Semarang, STIKES Ngudi Waluyo, Ungaran; (2007) 